\title{
Mercantour National Park - across the borders of sea and mountains, a beacon for the protection of our natural and cultural heritage
}

\author{
Alain Morand \& Pierre Commenville
}

\section{Abstract}

With nearly $2500 \mathrm{~km}^{2}$ of protected territory, the Mercantour National Park (PNM), with its Italian neighbour, the Parco Naturale Alpi Marittime, has become a beacon for the protection of biodiversity in Europe. For over 30 years, many targeted conservation projects have been carried out across this mountainous massif at the south-western tip of the Alps. Beyond the general protection of regulated areas in the core zone of the park $\left(963 \mathrm{~km}^{2}\right)$, some emblematic large mammals and birds such as the alpine ibex and the bearded vulture have benefited from population reintroduction and/or reinforcement programmes, legitimizing a voluntarist conservation policy that relies on the participation of numerous scientific partners, NGOs and other regional stakeholders (farmers, hunters, etc.). The involvement of local actors has also become a key element of conservation policy. With the natural return of wolves, linked to their expansion in Italy and through the Liguria region, several European programmes bringing together environmental and agricultural stakeholders have made it possible to develop better coexistence between farmers, shepherds and this newly installed predator, which has forced changes to grazing practices.

Today, PNM is at the crossroads of a number of changes. First, on the issue of scientific protocols and programmes, it particularly emphasizes their consistency across various networks, in the context of the global crisis of biodiversity. Second, the park is undergoing a major change in its mode of governance, collaborating with local actors to write a charter for the territory. These efforts towards development and a local takeover of natural resource management policy present a complex, dual challenge: to encourage initiatives and innovations from local actors in membership-based initiatives while enhancing the conservation of the natural and cultural heritage and the natural resources throughout the territory.
Profile

National Park

Mercantour

Mountain range

Alps

Country

France

\section{Historical approach and context}

France has nine national parks, four of which are located in one of Europe's mountain areas: Pyrenees, Vanoise, Ecrins and Mercantour. In harmony with a tradition of managing natural sites according to the principles of France's water and forests policies, the act of 22 July 1960 gave rise to the first parks. But it took many years of education and negotiation, often in an adversarial environment, before the mountain parks were finally created. Merveilleux du Vignaux (2003) describes the complex process of creating the French national parks very well, and emphasizes the difficulty of creating listed areas, motivated by a strong protective impulse, while at the same time maintaining traditional activities and avoiding the seizure of private property from its owners. More recently, Larrère et al. (2009) in their collective work have explored the various stages of acceptance / imposition in the history of the national parks. Mercantour National Park (PNM), though announced in 1962, would only be created 17 years later, in 1979 - the last such park on the French mainland. After some very difficult years, the park

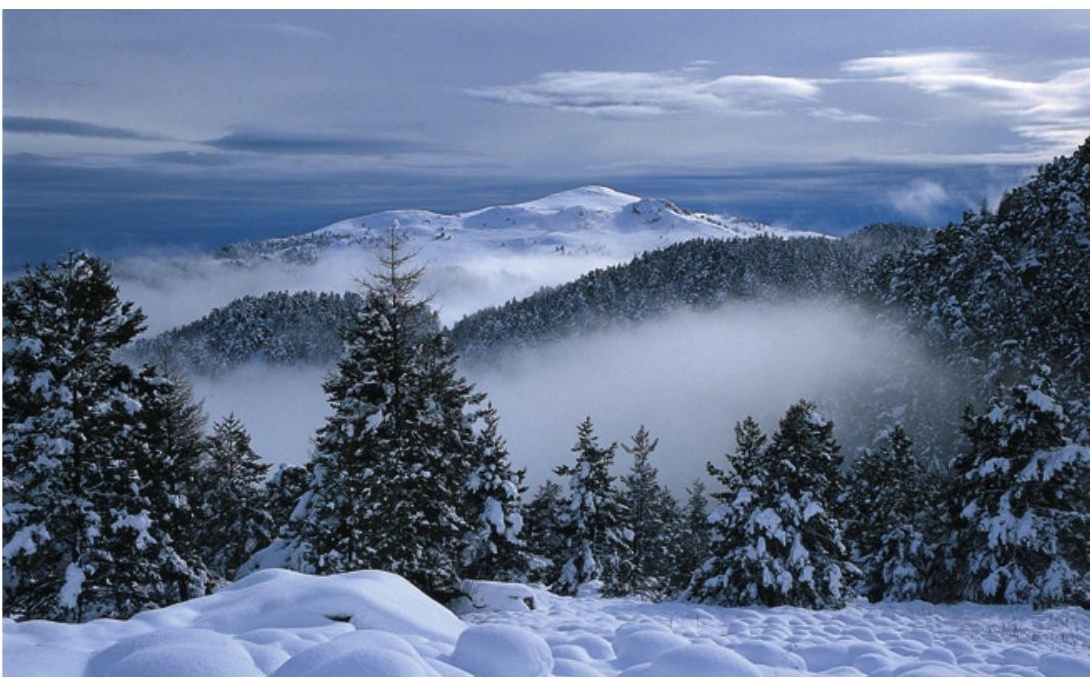

Figure 1 - Winter landscape in the Roya valley. (C) G. Rossi / PNM

took shape little by little, with the return to dialogue among elected officials, park managers and local stakeholders and land users, as is referred in Laslaz 2006. International recognition gradually increased, and PNM's core zone has been recognized since 1988 as a 


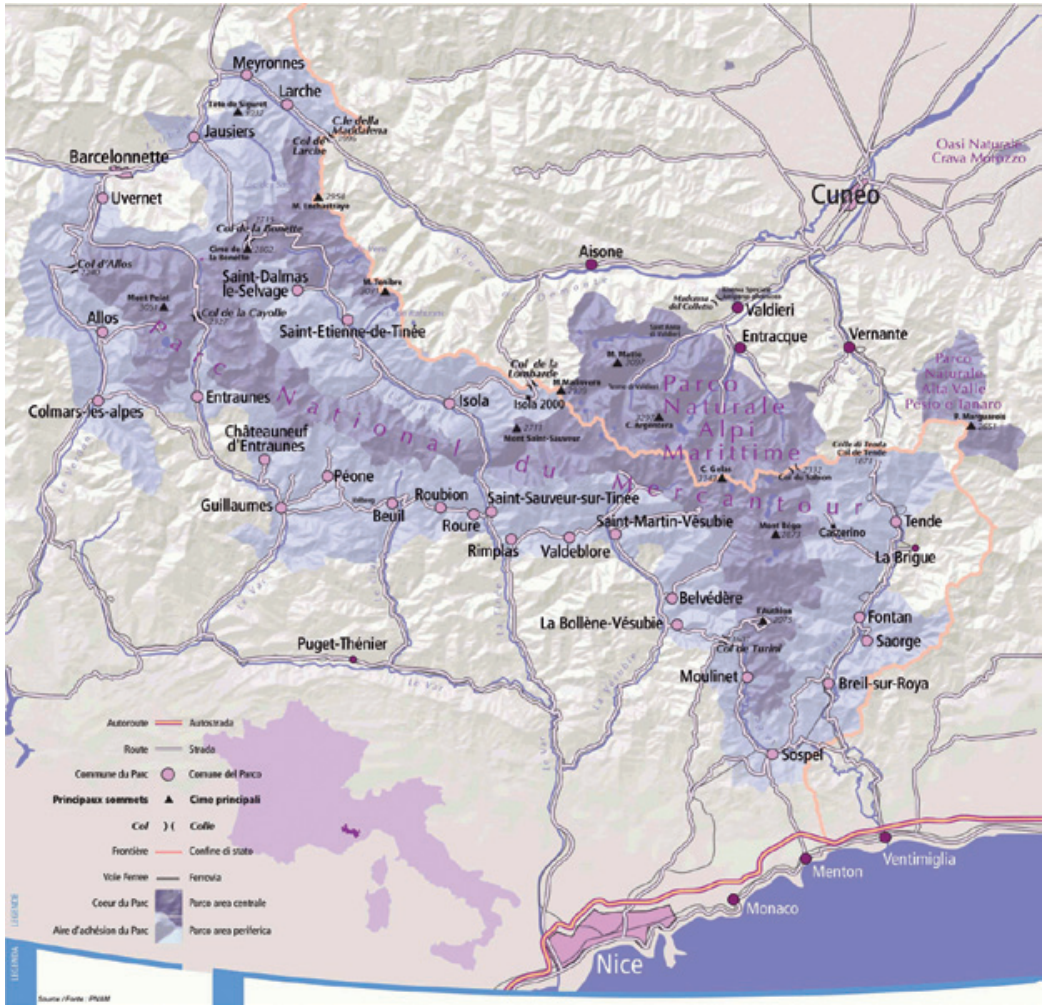

Figure 2 - General map of NPM \& PNAM. (C) PNAM

site in the Natura 2000 network established by the European Union's Birds Directive, and since 2003 by the Habitats Directive, in recognition of the importance of its natural habitats, wildlife (bats, amphibians, etc.) and flora. The site as a whole is one of the cornerstones of the Natura 2000 network in Europe thanks to its diversity of fauna, flora and important habitats and also because of its size. Located as it is near the border, PNM is twinned with its Italian neighbour, the

\section{Infobox}

\section{Intensive and exemplary cross-border collaboration since 1987}

Along the French-Italian border, the two parks have maintained extensive relationships since their inception. Intensive and exemplary collaboration today unites two institutions responsible for the conservation, management, and improvement of one coherent territory, with a common history and enjoying the same culture (Alpine Network of Protected Areas 2004). Twinning with the Alpi Marittime park began in 1987 and became consistent in the same year with a release of ibex. It continued with the first release of bearded vultures in 1993, the creation of a cross-border atlas of the natural and cultural heritage (PNM \& PNAM 2006), the implementation of a joint programme in 2006 (Dubost 2006) and finally the 2010 launch of an integrated cross-border initiative, funded by the European cooperation initiative ALCOTRA, with a total budget of some $€ 10$ million, which focuses on natural and cultural diversity and breaks down into 6 programmes (biodiversity, culture, mobility, education, tourism and planning). The two institutions are about to create a European Grouping for Territorial Cooperation, a legal entity that may undertake activities for the benefit of both parks, such as placing an area located in both parks jointly on UNESCO's World Heritage List.
Alpi Marittime Park (PNAM), and covers more than $2500 \mathrm{~km}^{2}$, of which $963 \mathrm{~km}^{2}$ are under strict protection, guaranteed by the French state for PNM and by the Piedmont region for the PNAM. This represents over $30 \%$ of the $8000 \mathrm{~km}^{2}$ of protected areas in the French Alps. Two other proposed twinning arrangements have yielded only sporadic exchanges: those with Banff National Park in Canada (established in 1885, $6500 \mathrm{~km}^{2}$ ) and the Zakouma National Park in Chad - doubtless because of the distances involved and the many differences between these parks.

PNM is also a living human territory with both traditional and modern aspects. The partnership zone of the park is home to 20000 people who live and work within its boundaries. As a result, both parks have gradually expanded their common outreach towards local partners outside the core zone and they are working harder to put more local stakeholders in contact with each other and to obtain financial resources for them rather than realizing projects by themselves.

\section{Physical environments, climate and hydrog- raphy}

A mountain massif with a crystalline core and a landscape shaped by glaciers

PNM is characterized by great geological diversity. At the southern end of the Alpine Arc, straddling France and Italy, stretches the southernmost external crystalline mountain massif of the Alps, called Argentera-Mercantour. It has an elliptical shape along a major north-west / south-east axis, and is dominated by peaks of max. $3200 \mathrm{~m}$. These metamorphic rock formations (schists, gneisses and amphibolites) to the north of the Roya and the Vésubie and to the east of the Tinée belong to the base of the ancient Hercynian chain (-300 million years), which was reshaped during the raising of the Alps in the Tertiary. To the south of the massif there are outcrops of detrital formations: sands and gravels, which long ago turned into sandstones or conglomerates or into fine sandstones or pelites as in Haute Roya, Moyenne Tinée and the red gorges of the Cians and the Var. In the gorges of the Var, also called the Daluis gorges, we find traces of the boundary between the Permian and Triassic and the biological crisis associated with it: the greatest in the history of the earth, with the disappearance of more than $90 \%$ of marine species. An intense volcanic crisis, general severe marine regression and strong climatic warming generated this major crisis.

Well-known among geologists, the Annot sandstones are found in the north-western part of the park and several series of very large sandstone formations can be observed in the Entraunes region. Finally, the crystalline core is surrounded by a ring of limestone or marly limestone pre-Alps of lower altitude. With more than twenty peaks over $3000 \mathrm{~m}$, the Argentera-Mercantour massif is characterized by its incised morphology and the narrowness of its valleys. The landscape 
was formed by the Würmian glacial period ( -70000 to -10000 years) that shaped the valleys and the glacial cirques (Landrieu, 2005).

The Alps under the influence of the sea

The Mercantour climate is strongly influenced by its proximity to the sea: the $3000 \mathrm{~m}$ summit nearest to the sea is only $39 \mathrm{~km}$ away from it. This results in a warm, sunny climate and relatively mild winters. Precipitation is irregularly distributed over the year, quite low in summer, despite violent thunderstorms, and peaking in the autumn.

In addition, PNM is at the centre of a climatic crossroads under the influence of the Mediterranean, with the addition of sea air and of land breeze / sea breeze phenomena, as well as Provençal, Ligurian and Alpine influences.

The combinations of these influences allow us to distinguish three main climatic zones:

- Provençal Mercantour: Moyenne Tinée, Haut Var,

Haut Cians, Southern Haut Verdon;

- Ligurian Mercantour: Roya and Bévéra, Vésubie, Eastern Haute Tinée;

- Alpine Mercantour: Ubaye, Western Tinée, and Northern Haut Verdon.

The climate characteristics change with increasing altitude, the intensity of sunlight, decreasing temperatures and persistent snow cover.

The drainage system is based on several macro-watersheds: there are six on the French side. The rivers have a torrential regime characterized by a strong increase in flow during the spring thaw and autumn rains. There are very many lakes: more than 220 bodies of water larger than 0.5 ha have been recorded (MEDD \& PNM 2002).

\section{Human activities and landscape}

From abandonment of the traditional settled farm to the expansion of migratory shepherding The diversity of the landscapes in PNM is created largely by the variety of land-use systems. While shepherding activities dominate in the park and use about $56 \%$ of the territory, its proximity to the Mediterranean has favoured the development and maintenance of highly diversified agricultural activities. Settled agriculture is orientated primarily ( $60 \%$ of the farms) to raising livestock. Half of the farms produce sheep for meat, a quarter mostly cattle for meat, and a quarter are dairy farms. These livestock operations are particularly extensive in PNM and mostly use natural grasslands, rangelands and pastures. The climatic conditions of Mercantour, including the eastern extremity, also allow the development of diversified agricultural activities using smaller areas with high added value: market gardening, fruit growing and beekeeping.

The pastoral area of PNM with tracks and grazing lands covers about 120000 ha. In 2008, 243 pastoral units were counted in the park, including 177 pastures.

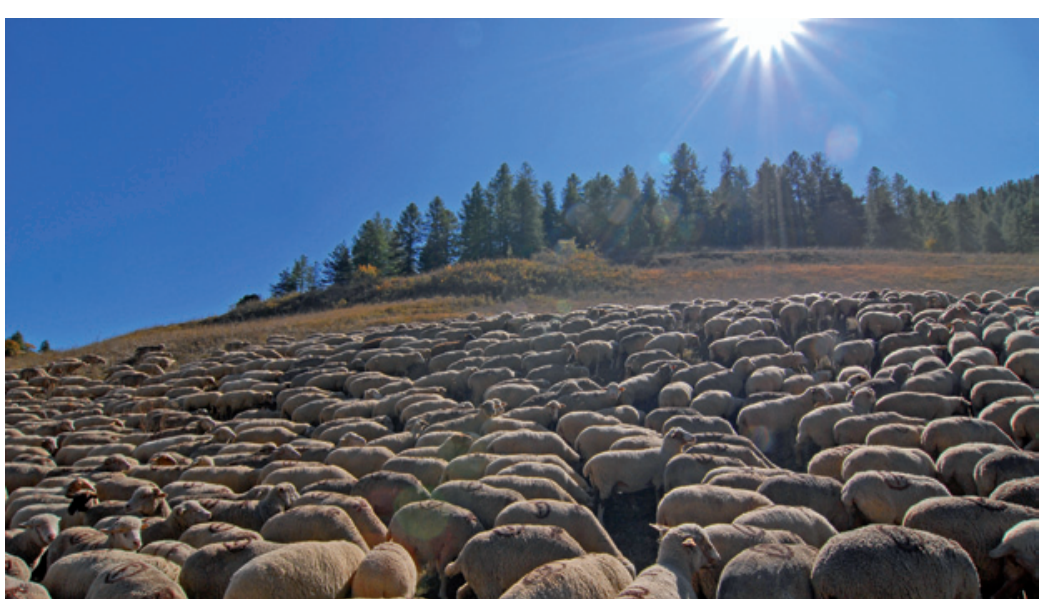

Figure 3-Men and their herds - the territory is deeply marked by long-distance migratory shepherding. (C) P. Pierini / PNM

The PNM area is known for the importance of migratory shepherding, with PNM's alpine pastures welcoming herds from the entire region in summer: of the approximately 145000 sheep present in the summer, 117500 are from municipalities outside the park. The agricultural dynamics of the park are reflected in intersecting trends: while settled farming is struggling to survive in the valleys, which are marked by abandonment, the higher pastoral area remains very popular and is used fully, mainly by farms engaged in migratory herding.

\section{Forest environments and forestry}

Forests cover one third or 22471 ha of the core zone of PNM (Landrieu 2005). The stands are mostly conifers. In the mountain area, Scots pine on the sunward slopes is opposed to thick forests of fir and spruce on the shady sides. Although it also occurs in the higher part, larch mainly dominates the subalpine zone, where the Cembro pine is found in scattered stands. Beyond 2200 metres, the forest gradually gives way to grasslands and heathlands, although there are larch and Cembro pine up to $2500 \mathrm{~m}$. Forest resources are generally underused because of operational constraints (topography and access). The woods are usually average or poor quality (building timber) and are mainly processed outside the park.

\section{Tourism and outdoor activities}

Winter sports are the main economic activity, with the eight Mercantour mountain resorts welcoming 2.6 million visitors annually. Walking brings approximately 400000 visitors per year to the core zone of PNM. There are other outdoor activities too: mountaineering and climbing, canyoning, via ferrata, snowshoeing, and ski touring. PNM management has intervened mainly by maintaining and restoring hiking trails, which today make up a network of over $600 \mathrm{~km}$. The vast majority of these trails are relics of the history of mountain travel, which was particularly intense, encompassing merchant routes, salt roads, transhumance routes for domestic cattle, and so on. 
The cultural dimension of the heritage protected by the park

Since the Act of 14 April, 2006, the national parks have a strong cultural mission to inventory and then protect various heritage objects. In PNM, the religious heritage is omnipresent: chapels, churches and cathedrals, frescoes, mosaics and altars, shrines, paintings, organs, carved crosses and pilgrimage sites, which are still maintained. More than half of them are listed, especially in the Roya, Tinée and Vésubie valleys. Border fortifications, another legacy from the past, include nearly 230 structures, covering a period from the Middle Ages to the Second World War. A very few of these have been recognized by a heritage classification as listed sites or monuments. Finally, there is the intangible heritage, i.e. the know-how, agro-pastoral and religious festive events, and oral traditions, all of which contribute to the identity of the Mercantour valleys and are therefore inventoried as part of the cross-border programme, there being little other work on the subject (Larrère, 2010).

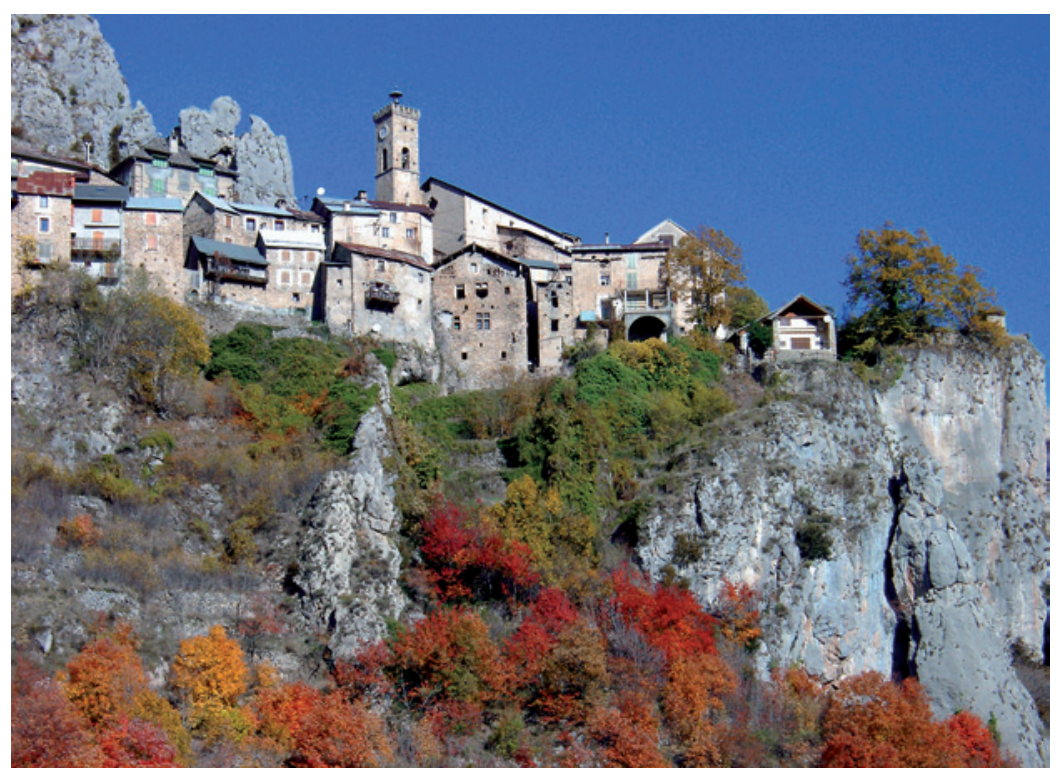

Figure 4 - Roubion, a typical perched village in the Tinée valley. (C) PNM

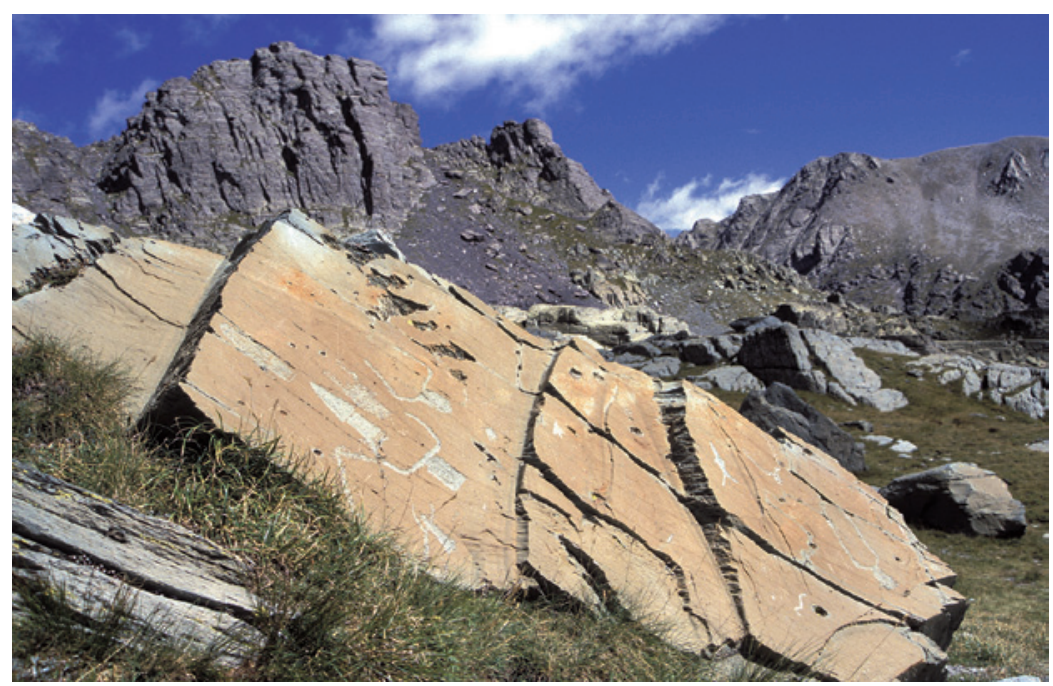

Figure 5 - Rock engravings of the Vallée des Merveilles. (C) G. Lombart / PNM
The Vallée des Merveilles of the Mont Bego region

In two valleys in the region of Mont Bego, in Roya - the Vallée des Merveilles and the Fontanalbe Valley - we find one of the richest open-air collections of rock engravings in Europe, both in terms of the large number of carvings (100000, of which 37000 are figurative) and the variety of processes (punched engravings, use of the relief of the rock and linear engravings made with a metal point), topics (ideograms, characters, poems and inscriptions by shepherds, soldiers or travellers, complex scenes, etc.) and periods (Chalcolithic, Bronze Age, early Christian era, Middle Ages, first half of the twentieth century). On some rocks you can still see today the "C" of Carlo Conti, who, from 1927 to 1942 marked, mapped, traced and cast around 35000 carvings. Starting in 1967, Professor Henry de Lumley, in collaboration with teams of archaeologists and students, undertook continuous research on the site and has offered interpretations of the engravings (De Lumley \& Clergue 2002). Five thousand years ago, this site, so difficult to access at an altitude of more than $2200 \mathrm{~m}$, was probably a sacred place reserved for initiates. These stylized signs, symbols or pictograms were designed to inscribe in stone certain sacred rites connected with the agricultural and pastoral concerns of local people and in this sense we can begin to speak of a proto-writing system. It would have been a symbolic language, essentially religious, where the images made it possible to establish communication with the divine. De Lumley maintains that several engravings explicitly refer to the sacrifice of bulls. According to Nathalie Magnardi, an ethnologist and conservation officer at the Musée des Merveilles in Tende, attention should be focused on the degradation of the rock carvings. One solution that she suggests is providing hikers with a large area where everyone can be an artist and express themselves freely. In 1999, PNM established a special protective system for this site. Visitors are accompanied when viewing the engravings as part of an inexpensive public service, made available at the entrance of the two main valleys. Enhanced surveillance of the engravings is set up during the summer, as the carvings are only free of snow for five months out of twelve.

\section{A mosaic of exceptional natural habitats, fauna and flora}

The endemic species: some examples of flora and fauna

Especially in terms of flora, the Southern Alps, and in particular the Argentera-Mercantour massif, are the major centre of endemism across the whole of the alpine chain. Some species are palaeo-endemic, like Berardia subacaulis, which is a relic of the Ice Age and the last representative in Europe of a botanical family that is found throughout Africa. Other neo-endemic species were differentiated in the post-glacial epoch 

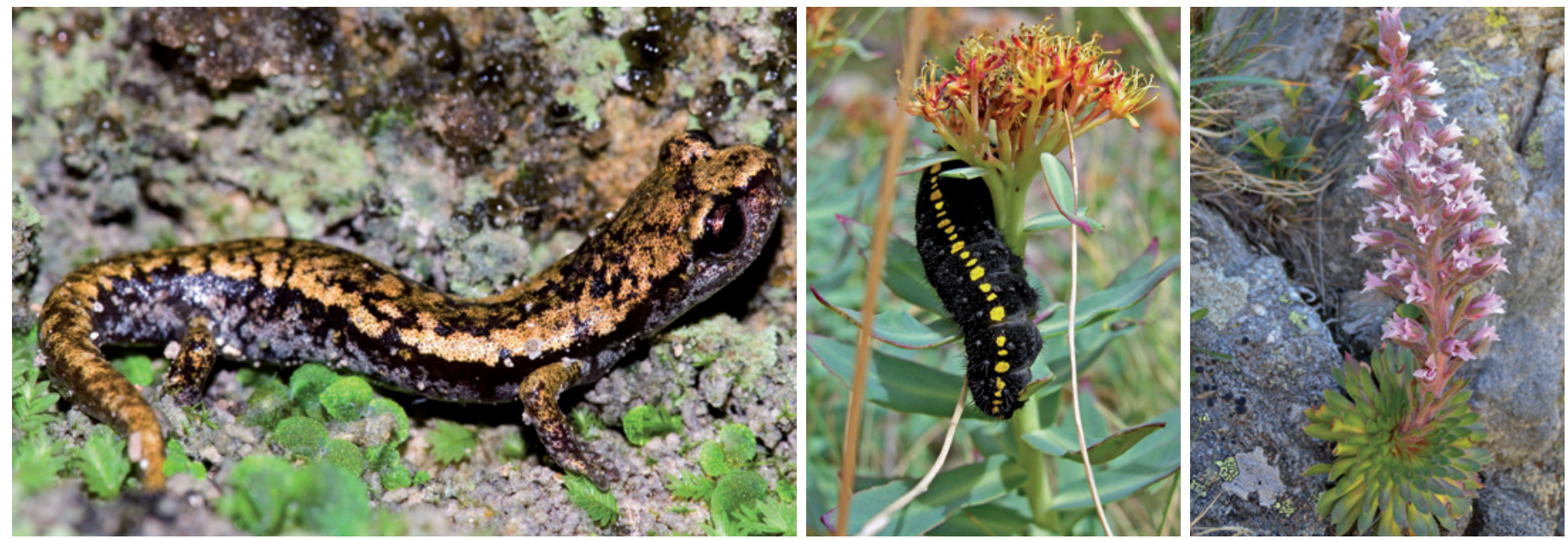

Figure 6-Speleomantes strinati, an endemic amphibian (left). (C) J. Lopez. Caterpillar of Small Apollo (Parnassius phoebus gazelli) on its host plant, Rhodiola rosea (middle). (C) A. Jourdan / PNM. Saxifraga florulenta, a siliceous specialist plant with woody stump deeply anchored in rock cracks, long served as the park's emblem (right). (C) A. Turpand/ PNM

(Saxifraga florulenta, Potentilla valderia, Silene cordifolia). In 2009, extensive research on the PNM flora delivered a new species for France's botanical heritage, Moehringia argenteria, endemic to the siliceous Argentera-Mercantour massif. This species had hitherto been known only on the Italian side, and was found only in Vésubie. For wildlife too, the massif is rich in endemism. At European level, PNM is responsible for Strinati's Cave Salamander (Speleomantes strinatii), a small cavedwelling and near-threatened amphibian listed in the French Red List of the IUCN and the only totally endemic vertebrate of the Argentera-Mercantour territory. While one in five species of amphibians, including many that are endemic, could disappear by 2050 (Temple \& Cox, 2009), the responsibility for conservation of this species is reflected in significant protective measures. Note also the examples of infraspecies endemism, including the brown trout (Salmo trutta fario) of Mediterranean ancestry in some heads of watersheds. Moreover, surveys conducted to date in aquatic environments highlight the great richness and diversity of populations of aquatic invertebrates, including the insect orders Trichoptera and Plecoptera. These two fami- lies alone are represented by more than 110 species, including many recently discovered endemic species, such as Apatania mercantour, endemic in the Southern Alps (Giudicelli \& Derrien 2009). As a first stage of conservation, knowledge of this poorly known fauna, previously omitted from national and international lists of protected species, is being expanded in a very ambitious project to complete an exhaustive census of the biodiversity of the parks (de Biaggi et al. 2010).

The Alpine ibex: stimulating cross-border cooperation

The Alpine ibex, which had virtually disappeared from the Alps in the early nineteenth century, was reintroduced into the royal reserve of Valdieri in Italy with individuals from Gran Paradiso. Unfortunately, from the small group of thirty individuals, only a dozen survived poaching and accidents and the population was weakened further by the Second World War from 1939 / 40. Nevertheless, when the park was established in 1979, less than a hundred individuals still occupied the Mercantour territory and the double Argentera side. Between 1985 and 1995, an expert group, known
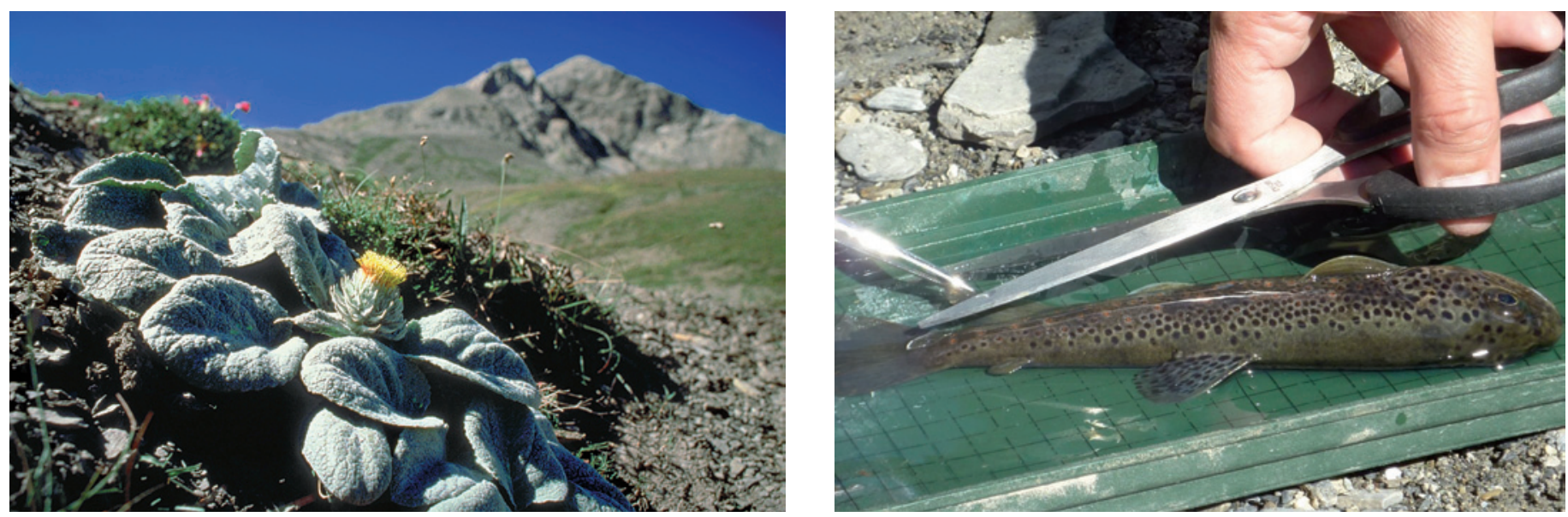

Figure 7 - Berardia subacaulis, this relic survived from a very distant past (left). (C) PNM. Population genetics study of Salmo trutta in the region of Lauzanier Lake (right). (C) Archive PNAM 


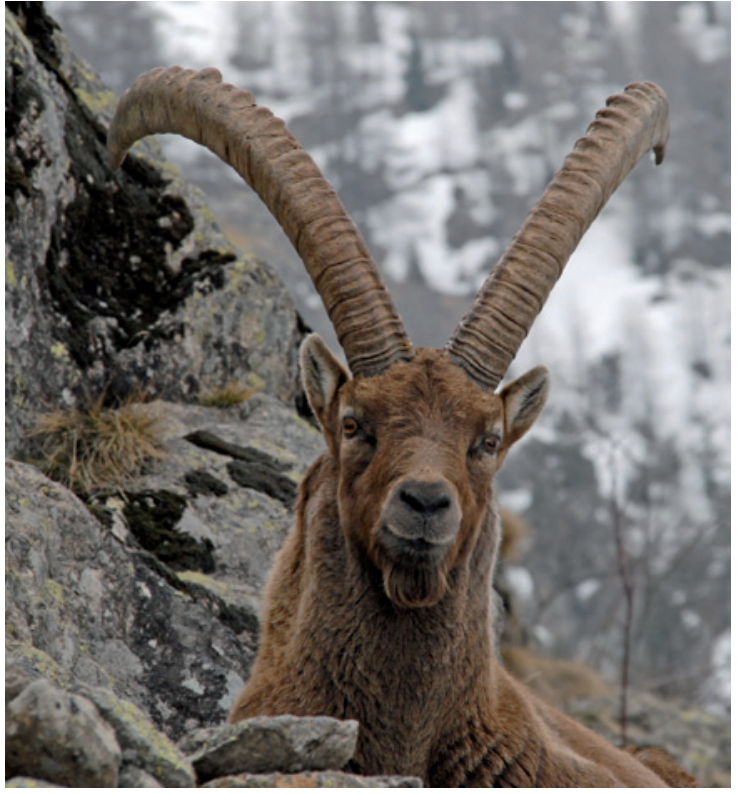

Figure 8-Alpine ibex (Capra ibex), the heaviest mammal at bigh altitude: return of a flagship species. (C) F. Guigo / PNM

as the "Bouquetin" group (French for ibex), was set up and organized a scientific programme to understand the population dynamics as well as the dispersal and colonisation of individuals, some of which were tagged, collared with VHF transmitters or Argos satellite boxes to facilitate tracking them (Terrier \& Rossi 1989). The gregarious nature of the species, leading to low dispersive capacity and low rate of creating new settlements, eventually led to specific reintroduction operations (Tour d'Allos, Saint-Ours). Additional releases took place, in particular to diversify the gene pool of the population (Maudet et al. 2002). Samples will be taken in PNM or in Vanoise. In 2009, it was estimated that about 1100 ibex were present in PNM, which remains a relatively low figure given the size of the area (about 0.5 individuals per square kilometre).

The natural return of wolves

After having disappeared from French territory for sixty years, in 1992 two individuals were definitely

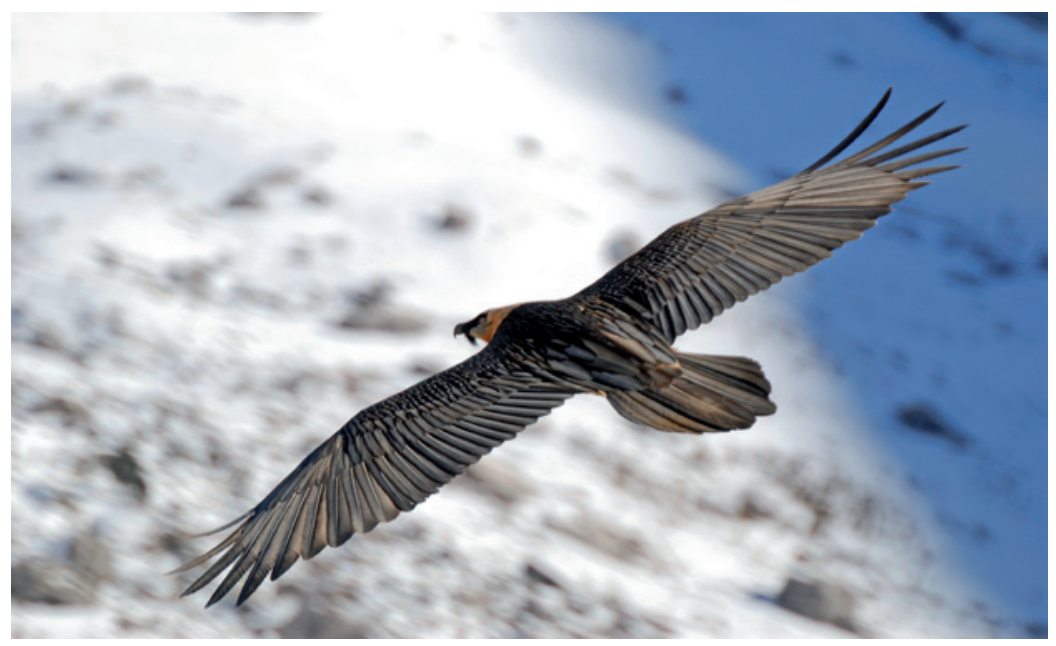

Figure 9-An adult bearded vulture in flight. (C) F. Breton / PNM observed in PNM. The official announcement appeared eight months later to the dismay of farmers and hunters (Fronzes 2010). Positive demographic development by the Italian wolf population in the Apennines, national and European protected status since the 1970s and an increase in ungulate populations all encouraged this Alpine expansion, which was confirmed by molecular studies in 1996. In 2009, there were seven to eight packs of wolves, or about thirty individuals, in the mountain massif between France and Italy. While the main prey species are wild ungulates, sheep may also be an important part of the diet, particularly in summer, causing damage to livestock and hostility from farmers. The management of this species in the context of pastoralism is part of a national action plan (2008-2012) carried out by the ministries responsible for ecology and agriculture. In this planning document (MEEDAT 2008), the Predator-Prey Programme is being implemented within the PNM territory under the scientific guidance of the Office $\mathrm{Na}$ tional de la Chasse et de la Faune Sauvage (National Office for Hunting and Wildlife) and the Centre National de la Recherche Scientifique (National Centre for Scientific Research) and in close collaboration with the PNM officials and those of the Fédération Départementale des Chasseurs (Departmental Federation of Hunters) of the Alpes-Maritimes. Its objective is to study the longterm effects of predation by a pack of wolves on the population dynamics of four species of ungulates (chamois, mouflon, red deer and roe deer) to test the hypothesis of prey selectivity and other spillover effects on ungulates. For this purpose, on the night of 12 July 2009, a female wolf was captured and marked. This wolf was tracked for about three months and provided information on dispersal distances and the area occupied over a fortnight, including rest areas and hunting areas. Then, in late March 2010, a second wolf ("Ylva") was captured and fitted with a collar, after having been shot with an anaesthetic dart from a helicopter. Sadly, she was found dead from sepsis as a result of an accident on 22 September 2010. Spatial data and the study of ungulate carcasses are currently being analysed and capture operations are also continuing.

A precarious success: the reintroduction of vultures

Numerous archaeological and literary references demonstrate that the Lammergeier or Bearded Vulture was present in most of the mountain ranges of the Northern and Southern Alps in historic and prehistoric times; but its decline over the last century has caused this emblematic bird of prey to become very scarce away from the population centres of the Pyrenees. This alarming development has led to the idea of a programme of reintroductions throughout the whole Alpine Arc, and specifically in two sites in the Southern Alps which offered a certain number of factors to make such a project feasible: the PNM and the Alpi Marittime Park. Confirmed by the National Council 
for the Protection of Nature in 1992, this project was put into motion in 1993 (Lequette \& Perfus 2000). In each of the two sites, a total of 35 Egyptian vultures obtained from various authorized breeding centres were released into the wild. In PNM, a radio-tracking study was carried out in 2007 and 2009 to determine the dispersion and possible settlement of the birds, the greatest distances they had travelled and the survival rate of the reintroduced individuals. The first phase of the project can be considered a success, especially as two birds seems to have settled and paired, giving us in 2008 "Parouart", the first individual reproduced in natura, at St Paul en Ubaye, which we hope will be the beginning of a viable population in these mountains. Monitoring of reproduction in 2009 and 2010, conducted by the PNM teams and a network of volunteers, unfortunately has failed to confirm reproduction, the causes of which are being studied. Under the French national action plan for the bearded vulture for 2010-2020, both parks will be included in the strategy most conducive for a viable metapopulation across the Alps (Schaub et al. 2009; MEDEM 2010).

The All Taxa Biodiversity Inventory + Monitoring programme

The programme for an exhaustive multi-taxa inventory of life was started in 2006 between the two parks with the participation of a network of natural history museums and botanical gardens throughout Europe (the network of the European Distributed Institute of Taxonomy, EDIT 2007). The objective is to study as many long neglected and long ignored species and habitats as possible. This is the case for many species of aquatic and terrestrial invertebrates (molluscs, crustaceans, insects, spiders, etc.), fungi, lichens and bryophytes, as well as environments such as caves, bogs or glacier-head snowfields, habitats which are under-surveyed, yet rich in biodiversity. Within the framework of the European ALCOTRA programme, the inventory of life will continue until 2012, building bridges between taxonomic science and conservation science, mainly to serve the interests of protected area managers. Currently more than 30000 data items (a third coming from the PNM core zone) have been entered into the CARDOBS database of the Inventaire National du Patrimoine Naturel (National Inventory of Natural Heritage) at the Museum of Natural History in Paris (www.inpn.fr), mainly providing information about faunal groups. The flora is better known but still the figures are immense at the European level. Of the 4900 species of pteridophytes and angiosperms inventoried in France, about 2400 are found in PNM. De Biaggi et al. (2010) synthesize the main results from the first two years. Furthermore, this inventory is designed to document the collecting methods to help future monitoring programmes. Several investigations have also been launched to monitor these poorly known life compartments, especially in the caves or small-sized bogs.

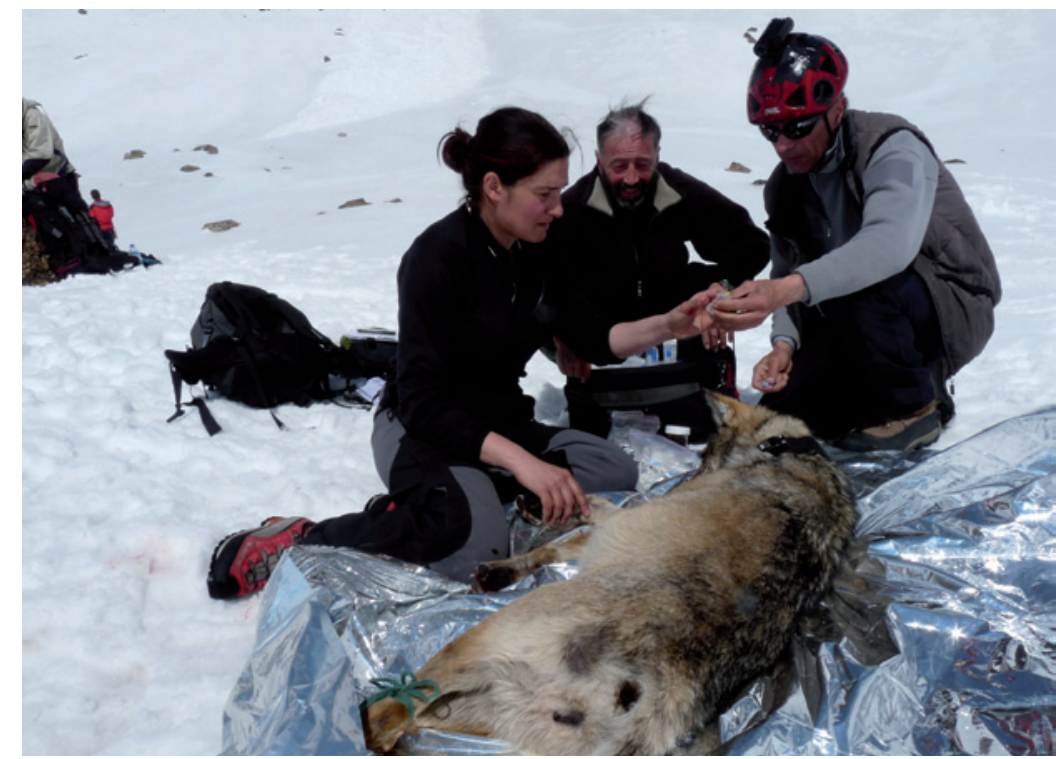

Figure 9-Veterinary and rangers realizing measurements and biopsy of the radio-tracked wolf "Ylva" in March 2010. (C) JP. Bergeon / ONCFS

Climate change and its impact on the distribution of high-altitude plant species

The GLORIA programme is an international programme of long-term monitoring of changes in vegetation in the world's mountains (www.gloria.ac.at and Pauli et al. 2009). Among the mountains studied since 2001 is the Mercantour massif, with study sites in Haute Tinée (Cime de Fer, Butte de Lausset, Cime des Babarottes, Mont Ténibres) under the leadership of the Centre de Biologie Alpine (Alpine Biology Centre), a laboratory of the CNRS and the Joseph Fourier University in Grenoble. Since 2003, every five years a record has been made from meteorological sensors and flora inventories are also being carried out.

\section{Infobox}

\section{What is the scientific programme of MNP for the next 10 years?}

A critical review of all protocols was conducted according to a participatory system (PNM 2010). The scientific programme has been revisited and is still the subject of exchanges between managers and scientists. The future programme will take into account the general context of sustainable development and new modes of governance of protected areas, particularly in terms of local participation, ecological networks which help the park and the need to build common tools within the French network of national parks and the Alpine Network of Protected Areas. This programme will also include the development of nature science and conservation through technological advances (databases and Geographic Information System, barcoding, etc.) and new forms of collaboration between the various land managers and researchers through programmes of "Science in Action" (Petit et al. 2008). These days the impact of global change on biodiversity conservation and of new threats to the life world are taken into account, a factor that may also have consequences for the development of human activities (invasions of exotic species, emerging diseases, etc.). 


\section{Conditions for social partnership in PNM land conservation policy}

In the course of their analysis of the relationships of societys with protected areas, several sociologists have suggested that public access is an important condition for "social partnership in conservation policy", since it is in protected areas that society's outlook on nature is formed (Depraz 2008). When PNM was created, a large number of potential visitors was highlighted as a benefit of the park. Thirty years later, we find that despite relatively low attendance figures compared with other mountain parks, numerous conflicts between conservation and welcoming the public have emerged, among them problems of disturbing wildlife and trampling flora. The park management has developed a strategy of controlling visits by means of a large team of supervisors (42 staff responsible for enforcement patrol PNM's $685 \mathrm{~km}^{2}$ ) and appropriate signage (information panels, reception areas and marked trails).

With the aim of integrating all citizens and users of this area, the park has developed educational programmes, exhibitions and conferences. These exceptional sites allow anyone an immersion in the wild and offer visitors a view of nature that is at once spectacular, soothing and restorative. Consequently, every year, PNM provides the framework for a large number of educational activities for schools at every level, mainly through the observation of flora and fauna.

Acceptance of the park is also being sought by a change in PNM governance, once fully controlled by the state. The participation of local stakeholders in decision-making is being encouraged by changing the operating rules of the board of directors. An economic, social and cultural council now makes it pos-

\section{Infobox}

\section{Opportunity to experience a different mode of governance: the Charter, a more participatory way to manage the territory}

Motivated by the ongoing difficulties experienced by the parks, including difficulties attributed to a lack of coherence and legitimacy, the French reform is in fact consistent with the general application, at international level, of an integration paradigm for the governance of protected areas (Depraz 2008). By requiring each park to collaborate with the municipalities in its region in writing a charter redefining its mission, its objectives and means to implement them, the Act of 14 April 2006 offers the French national parks the opportunity to become models of participatory governance, i.e. "the implementation of discussion, making it possible to express proposals and counter-proposals". But this rebirth will not be without its difficulties. The institution must in fact learn to present convincing arguments to other stakeholders, without the ability to promise unlimited financial assistance from the state. It must establish its credibility through a plan that clearly sets forth its level of intervention in the partnership zone: simple support in terms of image, technical assistance for public policy, or direct execution. The charter covers a period of twelve years. sible to bring together social and cultural stakeholders to take decisions about the park. Currently a plan is being drafted for intervention in PNM management outside the core area. This plan will take the form of a signed contract between the state and the municipalities at the periphery of the park, on a voluntary basis.

\section{Prospects}

PNM is turning a new milestone in its history. Drafting a sustainable development plan for the communities that benefit directly from the classification and regulation of the park's core zone will help resolve several problems: the issue of developing winter sports and their impact on the environment; the development of renewable energy sources which may be discovered in natural environments for the sake of energy independence or to find alternatives to fossil fuels; and preserving a sheep industry that is competitive but as environmentally compatible as possible. Above all, it aims to achieve the transition from traditional conservation systems to an integrated, cross-border action favouring biodiversity (Blandin 2010).

The involvement of PNM in these issues aims to improve the social acceptance of the protected area. Following Borrini-Feyerabend et al. 2004, we can identify three trends in the governance of the protected area:

Greater precaution overall in all planning processes

The need to provide knowledge and continuous updates of that knowledge is a challenge for a small mountain territory with multiple players. The management of the land at the periphery of the park will undergo a transformation. The identification of ecological continuity and expansion of cross-border cooperation will contribute to this.

Maintaining fairness in the decisions of the park For reasons that may be difficult to fathom, the park is considered by the local population as a form of confiscation of land by the state, and it will ultimately be accepted only if the principles of fairness in these founding texts are respected. Transparency in applying these principles must be further improved and the park must be made more accountable to society.

\section{Defining a shared vision}

We have seen concrete attempts to involve society in defining a vision for the future of the territory (Durieux 2010; Gumuchian 2010), particularly in 2008 during a symposium on pastoralism and biodiversity, where stakeholders converged on a shared vision on the subject (Chaufournier et al. 2008). This should be reproduced in the scheme of mountain lakes by establishing a programme of "Science in Action", involving water owners, fishermen and scientists from the beginning. 
In PNM, the idea is gaining ground that biodiversity is not a constraint but also an asset for the territory. That's good news.

\section{Acknowledgements}

The authors thank all their French and Italian colleagues and collaborators, whose help and support are crucial for the parks' protection. They acknowledge particularly those invested in scientific programmes and the providers of the pictures.

\section{References}

Alpine Network of Protected Areas (ed.) 2004. The ecological cross-border network border, a command of the Alpine Convention. In: Espaces protégés transfrontaliers et réseau écologique dans les Alpes. (Signaux alpins 3).

Audibert, C. 2010. Terre des hommes. In: L'Alpe 49 (ed.), Mercantour. Des monts et une mer.

Biaggi De, M., M. Leccia, A. Kroupa \& J-C. Monje 2010. Creating a biodiversity inventory in protected areas to increase knowledge of their natural heritage and to improve land management. eco.mont 2 (1): 49-52.

Blandin, P. 2010. De la protection de la nature au pilotage de la biodiversité. Quae (ed.).

Buisson, E., T. Dutoit, F. Torre, C. Römermann \& P. Poschlod 2006. The implications of seed rain and seed bank patterns for plant succession at the edges of abandoned fields in Mediterranean landscapes. Agriculture, Ecosystems \& Environment 115: 6-14.

Borrini-Feyerabend, G., A. Kothair \& G. Oviedo 2004. Indigenous and Local Communities and Protected Areas: Towards Equity and Enhanced Conservation. IUCN Gland (Switzerland) and Cambridge (UK).

Chaufournier F., R. Charmetant \& V. Boussou 2008. Retour sur les rencontres de Valdeblore, PNM.

De Lumley, H. \& C. Clergue 2002. Fascinant mont Bégo, Montagne sacrée de l'âge du Cuivre et de l'âge du Bronze ancien.

Depraz, S. 2008. Géographie des espaces naturels protégés. Genèse, principes et enjeux territoriaux. Collection U Géographie.

Dubost, M. 2006. Mercantour-Alpi Marittime : Plan d'action commun pour la protection et le développement durable. ICALPE.

Durieux, P. 2009. L'âge de raison ! Quel bilan ? Après 30 ans, quelle est la place de l'homme dans le parc? Dossier les 30 ans du parc. Echos du Mercantour 3: $18-22$

Fronzes, J.-P. 2010. Une histoire mouvementée. In: L'Alpe 49 (ed.), Mercantour. Des monts et une mer.

Giudicelli, J. \& M. Derrien 2009. Les invertébrés des eaux courantes du Parc national du Mercantour : inventaire, biogéographie et écologie. I. Trichoptères, Diptères Blépharicérides et Simuliidés. Ephemera 10: 43-69.

Gumuchian, H. 2010. Un territoire aux mille visages. In: L'Alpe 49 (ed.), Mercantour. Des monts et une mer.
Landrieu, G. 2005. Programme d'aménagement 20042010 du Parc national du Mercantour. MEEDAT, PNM.

Larrère, R. 2010. Une mosaïque de culture. In: L'Alpe 49 (ed.), Mercantour. Des monts et une mer.

Larrère, R., B. Lizet \& M. Berlan-Darqué (éd.) 2009. Histoire des Parcs nationaux. Comment prendre soin de la nature? Paris, Quae / MNHN.

Laslaz, L. 2006. Terre d'élevage ou « nature préservée » en zone centrale des parcs nationaux français des Alpes du sud. Méditerranée 3/4: 56-64.

Lequette, B. \& M. Perfus M. 2000. La réintroduction du gypaète barbu dans le Parc national du Mercantour. Le Courrier de la Nature, SNPN 182: 42-44.

Magnardi, N. 2010. Mots et Merveilles. In: L’Alpe 49 (ed.), Mercantour. Des monts et une mer.

\section{Infobox}

The concept of ecological solidarity, towards a territorial pattern of biological, social, economic and cultural corridors in MNP

Habitat fragmentation is considered as one of the most serious threats to biodiversity and one of the leading causes of the current extinction crisis. In fragmented landscapes, movement is a key process for the survival of populations (Wiens et al. 1993). Maintaining connectivity between wildlife and plant populations is one of the issues covered in the Grenelle de l'Environnement debate and implementation of the green and blue web is one mechanism for preserving the ecological continuity enshrined in law since 2010. Taking account of these interconnections and features in the regulatory requirements governing the core zone, as well as the guidelines applicable to the optimal partnership zone, will ensure diversity, the survival of populations and the resilience of habitats and their essential functions.

\section{Elements of a blue web: continuity of water flow and species}

Almost all of the watersheds of the partnership zone are fed by rivers with sources in the core of PNM. These streams, creeks and rivers constitute a significant portion of the high basins that feed the Riviera population of ca. 1 billion persons and provide ecological continuity for water and sediment transport as well as for the aquatic biodiversity thriving in these running waters. Identifying the most important continuities will help to preserve and, if needed, restore them.

The mountain lakes, however, are not interconnected. They represent so many islands, some of them large, and all are worth preserving as well as enhancing their undisturbed functioning (life diversity, seasonal flows of water...).

\section{Elements of a green network: maintenance of connections and features} PNM lies in a very steep mountain region little fragmented by habitat destruction or man-made infrastructures. Thus, we ought to consider the exterior threats. Climate change and pollutions will affect mainly the subalpine and alpine habitat, which will tend to decrease. As these habitats are key refuge for a special fauna (i.e. rock ptarmigan) and flora, their different patches should remain interconnected. We identify these high-altitude refuges and potential decreases. This needs all the more attention as there is a regular flow between Mediterranean habitats and the high-altitude zone, because of migratory herding. The domestic animals are carrying seeds of Mediterranean plants that will promote the vegetation changes privileged by climate change (Buisson et al. 2006). Besides, maintaining hay production and other resources for animals at low altitude could prevent the higher habitats, often composed of pastures, being overgrazed. Wider-scale effects should also been considered since the connections between high altitude habitats of Argentera-Mercantour with their neighbours (Queyras in the north, Ligurian Alps in the east) are geographically very narrow. 
Maudet, C., C. Miller, B. Bassano, C. Breitenmoserwürsten, D. Gauthier, C. Obexer-ruff, J. Michallet, P. Taberlet \& G. Luikart 2002. Microsatellite DNA and recent statisticals methods in wildlife conservation management: Application in Alpine ibex (Capra ibex ibex). Molecular Ecology 11: 421-426.

Merveilleux du Vignaux, P. 2003. L'aventure des parcs nationaux. La création des Parcs nationaux français, fragments d'bistoire.

Ministère de l'Ecologie et du Développement Durable \& Parc national du Mercantour (sous la coordination de Claudin J. \& JY. Biancheri) 2002. Atlas des Parcs nationaux de France, Parc national du Mercantour.

Ministère de l'Ecologie, de l'Energie, du Développement durable et de la Mer 2010. Plan national d'actions en faveur du Gypaète barbu (Gypaetus barbatus) 2010-2020.

Ministère de l'Ecologie, de l'Energie, du Développement durable et de l'Aménagement du territoire 2008. Plan d'action national sur le loup 2008-2012, dans le contexte français d'une activité importante et traditionnelle d'élevage.

Parc national du Mercantour (sous la coordination de Morand, A. \& J. Grandadam) 2010. Démarche d'évaluation et de hiérarchisation des protocoles d'inventaires et de suivis scientifiques.

\section{Infobox}

\section{Mercantour National Park}

Established in 1979

Region: Southern France, Provence-Alpes-Côte d'Azur

Main type of ecosystem: alpine valley

Major habitats \& type of land cover:

- urban zone: $0.5 \%$

- agriculture zone: $1.8 \%$

- forests: $39.6 \%$

- pastures and alpine grassland: $44 \%$

- shrubs: $3.8 \%$

- bare soils and rocks: $10.2 \%$

- water bodies: mountain, sub-alpine and alpine streams, lakes and peat bogs: $0.1 \%$

Location (latitude \& longitude):

$44^{\circ} 29^{\prime} \mathrm{N}$ to $43^{\circ} 50^{\prime} \mathrm{N}$ and $6^{\circ} 30^{\prime} \mathrm{E}$ to $7^{\circ} 42^{\prime} \mathrm{E}$ (maximal extension)

Total size:

$2147 \mathrm{~km}^{2}$, core zone $6850 \mathrm{~km}^{2}$, partnership zone $14627 \mathrm{~km}^{2}$

Altitudinal range (meters above sea level):

$490 \mathrm{~m}$ (Gorge de la Bevera) -3 143 m (Mont Gélas)

Number of inhabitants in the core zone: $<10$

Number of inhabitants in the partnership zone:

between 19000 and 20000 for 28 towns

Management offices: Mercantour National Park

23, rue d'Italie, 06000 NICE cedex 01, France

Web: www.mercantour.eu

Tel. +33 (4) 93161888

6 visitor centres and 19 information points provide - access to detailed information about PNM and Alpi Marittime Natural Park, - multipurpose halls for educational activities, films, conferences and temporary exhibitions.
Pauli, H., M. Gottfried, C. Klettner, S. Laimer \& G. Grabherr 2009. A Global Long-term Observation System for Mountain Biodiversity: Lessons Learned and Upcoming Challenges. In: Sharma, E. (ed.), Proceedings of the International Mountain Biodiversity Conference: 120-128. ICIMOD, Kathmandu.

Petit, S., P. Fleury, V. Michel \& C. Mougenot 2008. Raconter la recherche-intervention. Retour sur trois opérations de gestion de la biodiversité. Natures Sciences Sociétés 16: 326-336.

PNM \& PNAM 2006 (sous la coordination de Villani, N., G. Bernadi, L. Arro, P. Commenville \& J.-Y. Biancheri). Atlas du patrimoine naturel et culturel Mercantour-Marittime.

Schaub, M., R. Zink, H. Beissmann, F. Sarrazin \& R. Arlettaz 2009. When to end releases in reintroductions programmes: demographic rates and population viability analysis of bearded vultures in the Alps. Journal of Applied Ecology 46: 92-100.

Temple, H.J. \& N.A. Cox 2009. European Red List of Amphibians. Luxembourg. Office for Official Publications of the European Communities.

Terrier, G. \& P. Rossi 1989. Le bouquetin (Capra ibex ibex) dans les Alpes maritimes franco-italiennes : Occupation de l'espace, colonisation et régulations naturelles. Travaux scientifiques Parc national de la Vanoise XVIII: 271-288.

Wiens, J.A., N.C. Stenseth, B. Van Home \& R.A. Ims 1993. Ecological mechanisms and landscape ecology. Oikos 66: 369-380.

\section{Authors}

\section{Alain Morand}

Born in 1965, he is an environmental sciences engineer with a $\mathrm{PhD}$ in ecology, author or co-author of more than 40 papers on wildlife (wild boar, birds, butterflies Maculinea and all the more amphibians) and management schemes in protected areas. He is currently head of the scientific service of Mercantour National Park. alain.morand@mercantour-parcnational.fr

\section{Pierre Commenville}

Born in 1975, has a postgraduate degree in evolutionary ecology and is a public engineer in environmental sciences. After managing several conservation projects for the French National Forest Service, he has been working for eight years for Mercantour National Park and is currently its deputy director.

pierre.commenville@mercantour-parcnational.fr 